\title{
PENGEMBANGAN KEGIATAN BELAJAR ILMU PENGETAHUAN ALAM - KIMIA MELALUI METODE PENGAJARAN 'PQ4R' SEBAGAI UPAYA MENINGKATKAN AKTIVITAS DAN HASIL BELAJAR PADAPESERTA DIDIK STUDI KASUS KELAS XI DI SMA NEGERI 1 SIBOLGA
}

\author{
Hotmaria Siagian \\ Sekolah Menengah Atas Negeri 1 Sibolga \\ hotmariasiagian@gmail.com
}

\begin{abstract}
Abstrak: Penelitian ini bertujuan: (1) meningkatkan hasil belajar peserta didik; (2) mengetahui respon peserta didik melalui Pendekatan Pembelajaran dengan Metode PQ4R (Preview, Question, Read, Reflect, Recite and Review) pada mata pelajaran IPA-Kimia. Penelitian ini adalah penelitian dikhususkan dengan subjek peserta didik kelas XI SMA Negeri 1 Sibolga mata pelajaran IPA-Kimia. Adapun pemberian angket yang diberikan oleh peneliti kepada peserta didik untuk mengetahui respon terhadap pelaksanaan pembelajaran IPA-Kimia melalui metode PQ4R ternyata dapat dilihat dari hasil angket mencapai lebih dari 70\%, yakni menunjukkan kriteria penilaian baik. Rata-rata nilai tes evaluasi yang dicapai pada kondisi awal sebesar 58,83. Peserta didik yang memperoleh nilai di bawah 65 sebanyak 15 orang atau 50\%. Fakta menunjukkan bahwa peserta didik belum bisa menyelesaikan soal yang diberikan oleh guru, dan enggan untuk menyampaikan ide-ide mereka. Oleh karena itu, untuk lebih meningkatkan hasil belajar IPA-Kimia, dalam hal ini peneliti menggunakan alternatif dengan Pendekatan Pembelajaran dengan Metode PQ4R. Setelah dilakukan tindakan kelas, diperoleh suatu hasil positif, pada hasil penelitian siklus I menunjukkan bahwa prosentase dan nilai ratarata mencapai 5,97 dengan ketuntasan belajar 23,33\%. Untuk siklus II mencapai 6,84\% dengan dengan ketuntasan belajar 53,33\%. Pada siklus III mengalami peningkatan dengan rata-rata hasil tes 8,18 dengan ketuntasan belajar sebesar 86,66\%. Dengan demikian dapat disimpulkan bahwa penerapan pembelajaran melalui Pendekatan Pembelajaran dengan Metode PQ4R dapat meningkatkan hasil belajar IPA-Kimia peserta didik.
\end{abstract}

Kata Kunci: Pendekatan Pembelajaran, Metode PQ4R, Hasil Belajar

\begin{abstract}
Abstract: This study aims to: (1) improve the learning outcomes of students; (2) knowing the response of students through the PQ4R Method Learning Approach (Preview, Question, Read, Reflect, Recite and Review) in science-chemistry subjects.This research is a study devoted to the subject of students grade XI high school Negeri 1 Sibolga science-chemistry subjects.The provision of questionnaires given by researchers to students to know the response to the implementation of IPA-Kimia learning through the PQ4R method can be seen from the results of the questionnaire reaching more than 70\%, namely showing good assessment criteria.The average evaluation test score achieved in the initial condition was 58.83.Students who scored below 65 were 15 or 50\%.The fact shows that students of grade XI high school Negeri 1 Sibolga have not been able to solve the problem given by the teacher, and are reluctant to convey their ideas. Therefore, to further improve the study results of IPA-Chemistry, in this case researchers used alternatives with the Learning Approach with the PQ4R Method.After the class action, a positive result was obtained, in the results of cycle I research showed that the percentage and average score reached 5.97 with a study completeness of $23.33 \%$.For cycle II reached $6.84 \%$ with $53.33 \%$ learning completed. In cycle III it improved with an average test result of 8.18 with a study completeness of $86.66 \%$.Thus it can be concluded that the application of learning through the Learning Approach with PQ4R Method can improve the results of learning IPA-Chemistry of class XI students.
\end{abstract}

Keywords: Learning Approach, PQ4R Method, Learning Outcomes

\section{PENDAHULUAN}

Kimia merupakan salah satu mata pelajaran dalam rumpun sains yang sangat erat kaitannya dengan kehidupan sehari-hari. Sains berkaitan dengan cara mencari tahu dan memahami tentang alam. Pendidikan sains merupakan wahana bagi siswa untuk mempelajari dirinya sendiri dan alam sekitarnya serta menekankan pada pemberian pengalaman langsung, sehingga siswa perlu dibantu mengem- bangkan sejumlah keterampilan proses mengamati dengan seluruh indra, mengajukan hipotesis, dan menggali serta memilih informasi faktual yang relevan untuk menguji gagasan-gagasan untuk memecahkan masalah sehari-hari. Ilmu kimia termasuk ke dalam 
sains, sehingga pembelajaran kimia seharusnya berupaya untuk membekali siswa dengan berbagai kemampuan tentang cara mengetahui dan menjelaskan setiap fenomena yang terjadi di alam baik yang bersifat konkrit sampai yang bersifat abstrak.

Program pendidikan sangat penting sebagai sarana untuk meningkatkan peranan dan kualitas diri seseorang sebagaimana dalam peraturan perundang-undangan pemerintah Republik Indonesia tentang Sistem Pendidikan Nasional yang menjelaskan fungsi dan tujuan pendidikan nasional. Peran pendidikan merupakan suatu kondisi sangat penting bagi manusia, negara maupun pemerintah. Pendidikan diharapkan mampu mengatasi masalah-masalah yang sedang dihadapi karena pendidikan itu sendiri merupakan institusi penting bagi proses penyiapan dan meningkatkan kualitas sumber daya manusia yang benar-benar berkualitas.

Pendidikan Kimia memiliki potensi yang besar dan peranan yang strategis dalam menyiapkan sumber daya manusia yang berkualitas untuk menghadapi era industrial dan era globalisasi. Potensi ini dapat terwujud jika Pendidikan kimia mampu memberikan pengalaman belajar kepada siswa sesuai dengan tuntutan zaman. Oleh sebab itu, proses pembelajaran di sekolah menjadi sorotan penting untuk meningkatkan SDM yang berkualitas.

Pembelajaran yang selama ini terjadi di dalam kelas belum mampu menarik perhatian sehingga siswa terkesan apatis terhadap materi yang disampaikan guru. Siswa yang aktif bertanya atau menjawab pertanyaan guru atau temannya masih sangat rendah. Bahkan dalam satu kali tatap muka terkadang tidak ada satupun yang bertanya atau menjawab pertanyaan.

Rendahnya motivasi siswa terhadap pelajaran Ilmu Pengetahuan Alam-Kimia mengakibatkan sikap ingin tahu dan rasa solidaritas antar siswa dalam belajar menjadi kurang, serta proses pembelajaran yang monoton yaitu dengan menggunakan metode ceramah, membuat siswa kurang tertarik terhadap pelajaran Ilmu Pengetahuan AlamKimia. Sehingga ketuntasan belajar IPA belum mencapai indikator keberhasilan.

Untuk mengatasi masalah tersebut perlu diterapkan Pendekatan Pembelajaran dengan Metode PQ4R (Preview, Question, Read,
Reflect, Recite and Review) dalam pembelajaran kelompok. Metode $P Q 4 R$ merupakan penyempurnaan dari metode PQRST (Preview, Question, Read, State and Tes) dan SQ3R (Survey, Question, Read, Recite and Review). Metode belajar tersebut adalah cara mempelajari teks (bacaan) khususnya yang terdapat dalam buku, artikel ilmiah dan laporan penelitian secara spesifik untuk memahami isi teks tersebut. Metode PQ4R dapat membantu siswa untuk mengingat apa yang telah dibaca dan mengajarkan kepada siswa untuk mengingat apa yang telah dibaca dan mengajarkan kepada siswa tentang bagaimana belajar, bagaimana mengingat dan bagaimana berfikir.

Agar pelaksanaan pembelajaran dengan menggunakan metode PQ4R berhasil dengan baik, maka dibutuhkan waktu yang cukup dan siswa lebih rajin, cermat serta teliti. Dalam pembelajaran kooperatif, siswa akan belajar secara berkelompok dan diberikan kesempatan lebih aktif dalam kegiatan belajar. Sehingga terdapat peluang lebih besar untuk memahami metode PQ4R dan meningkatkan hasil belajar Ilmu Pengetahuan Alam-Kimia.

\section{Belajar dan Pembelajaran}

Menurut Witherington dalam Nana Syaodih Sukmadinata, belajar merupakan perubahan dalam kepribadian, yang dimanifestasikan sebagai pola-pola respons yang baru yang terbentuk keterampilan, sikap, kebiasaan, pengetahuan dan kecakapan". Menurut Clifford T. Morgan, Belajar adalah Learning is can be defined as any relatively permanent change in an organism behavioral repertoire that occurs as a result of experience.

Belajar adalah perubahan tingkah laku yang relatif tetap bahkan merupakan pengalaman masa lalu. Dengan demikian dapatlah dikatakan bahwa belajar itu sebagai rangkaian kegiatan jiwa raga, psiko-fisik untuk menuju ke perkembangan pribadi manusia seutuhnya, yang berarti menyangkut unsur cipta, rasa dan karsa, ranah kognitif, afektif, dan psikomotorik.

\section{Hasil Belajar}

Hasil belajar adalah kemampuankemampuan yang dimiliki peserta didik setelah ia menerima pengalaman belajarnya. Yang menjadi tolok ukur bukan hanya nilai atau skor tetapi juga 
Kondisi umum jasmani dan tonus (tegangan otot) yang menandai tingkat kebugaran organ-organ tubuh dan sendisendinya, dapat mempengaruhi semangat dan intensitas siswa dalam mengikuti pelajaran. Kondisi organ tubuh yang lemah, dapat menurunkan kalitas ranah cipta (kognitif) sehingga materi yang dipelajaripun kurang tau atau tidak membekas.

\section{Pembelajaran IPA-Kimia}

Kimia adalah bagian dari IPA, sehingga karakteristik yang dimiliki IPA berlaku juga untuk Kimia yang pada akhirnya akan mempengaruhi pelaksanaan pengajaran Kimia. Menurut Gerthsen (1985) yang dikutip oleh Druxes (1986): "Kimia adalah suatu teori yang menerangkan gejala-gejala alam sesederhana mungkin dan berusaha menemukan hubungan antara kenyataan-kenyataan persyaratan utama untuk pemecahan soal adalah dengan mengamati gejala-gejala tersebut". Sedangkan menurut pendapat Brockhaus (1972) yang dikutip oleh Druxes (1986): "Kimia adalah pelajaran tentang kejadian alam yang memungkinkan penelitian dengan percobaan dan pengujian secara sistematis dan berdasarkan peraturan umum".

Dari beberapa pendapat tentang Kimia di atas dapat disimpulkan bahwa Kimia adalah salah satu cabang dari IPA yang menerangkan gejalagejala alam yang bersifat fisik yang dapat dipelajari melalui pengamatan, eksperimen, serta teori. Secara pengamatan dan eksperimen, Kimia dapat dipelajari di alam secara langsung di laboratorium, sedangkan secara teori Kimia dapat dipelajari dengan kegiatan berdasarkan analisis rasional dengan berpijak pada teori yang telah ditemukan sebelumnya. Hasil-hasil Kimia diungkapkan dalam bentuk fakta, konsep, prinsip, hukum dan teori. Kimia meliputi proses, sikap, dan produk. Proses Kimia berupa aktivitas-aktivitas yang bertujuan mempelajari, menggali, mencari, dan menyelidiki kejadian alam. Sikap Kimia berupa sikap mental yang diperlukan selama melakukan proses kegiatan Kimia (jujur, terbuka, kritis, menghargai pendapat orang lain). Produk Kimia adalah hasil kegiatan Kimia berupa konsep, hukum, dan teori yang tersusun berdasarkan fakta-fakta alam.

Mata pelajaran Kimia mempunyai tujuan yang akan dicapai. Tujuan pengajaran Kimia secara umum dapat dirumuskan sebagai berikut:

a. Agar anak didik memahami ilmu yang membicarakan dan di mana mereka hidup.

b. Membangkitkan dan menumbuhkan perhatian terhadap Kimia, ini dapat dicapai melalui:

1. Menggunakan metode mengajar yang sesuai

2. Mengajarkan konsep-konsep Kimia yang modern

3. Menunjukkan hubungan antara Kimia dengan lingkungannya

c. Membangkitkan sikap ingin tahu. Hal ini dapat dicapai melalui:

1. Mengajukan banyak persoalan pada siswa

2. Merangsang anak didik mengadakan pengamatan atau percobaan

d. Mengajarkan anak didik berpikir ilmiah

e. Menumbuhkan keterampilan dasar tertentu yang diperlukan pada penyelidikan sederhana.

f. Menekankan adanya hubungan antara Kimia dengan bidang ilmu yang lain. (Druxes, 1986)

Menurut Piageat yang dikutip dari Suparno (2007): "pengetahuan datang dari tindakan". Perkembangan kognitif sebagian besar bergantung pada seberapa aktif anak memanipulasi dan berinteraksi dengan lingkungan. Perkembangan kognitif bukan akumulasi dari kepingan informasi terpisah, namun lebih kepada pengkonstruksian oleh siswa untuk memahami lingkungan mereka. Berdasarkan hal tersebut, dalam pembelajaran Kimia, guru seharusnya hadir sebagai fasilitator bagi siswa dalam mengkonstruksi pemahaman dan pengetahuannya.

Menurut Hassard (2005) yang dikutip oleh Supriyono (2012: 23), pembelajaran Kimia menyajikan tidak hanya fakta-fakta dan informasi Kimia, tetapi juga proses Kimia kepada siswa. Dengan demikian, pembelajaran Kimia berkewajiban menciptakan lingkungan kelas yang menumbuhkan nilai-nilai ilmiah yang sama dengan Kimiawan terdahulu yaitu seberapa jauh siswa diberi kesempatan untuk mengembangkan ideideya, apakah aktivitas di dalam kelas dirancang untuk memunculkan jawaban-jawaban dan penyelesaianpenyelesaian alternatif, apakah siswa didorong untuk mengidentifikasi dan kemudian mencoba untuk memecahkan masalah yang relevan, dan apakah masalah-masalah yang mereka pecahkan memiliki konsekuensi-konsekuensi 
dalam kehidupan mareka.

Harlen dalam Purwati (2012: 3) menambahkan, karakteristik pembelajaran Kimia antara lain: (1) merupakan ilmu yang berhakekat pada proses dan produk, artinya dalam belajar Kimia tidak cukup hanya mempelajari produknya melainkan juga menguasai cara memperoleh produk tersebut; (2) produk Kimia cenderung bersifat abstrak dan dalam bentuk pengetahuan fisik dan logika matematik. Oleh karena itu, pembelajaran Kimia yang penyajiannya melibatkan siswa secara aktif baik dari segi mental maupun fisik dan bersifat nyata (konstekstual) akan menjadi semakin menarik. Dengan demikian pembelajaran Kimia memberikan kesempatan seluas-luasnya kepada siswa untuk mencari, mempertanyakan dan mengeksplorasi pengetahuan.

Widhy (2013: 2) menambahkan bahwa selain Kimia merupakan ilmu yang berhakekat pada proses (a way of investigating) dan produk (a body of knowledge), Kimia sebagai bagian dari IPA juga merupakan ilmu yang berhakekat pada sikap (a way of thinking). Kimia sebagai proses mengandung arti bahwa ciri seorang saintis harus memecahkan persoalan berdasar pada metode ilmiah yang dapat diterima secara logis. Produk Kimia merupakan hasil yang diperoleh dari kegiatan ilmiah, dapat berbentuk konsep, teori, hukum dan postulat, produk ini diharapkan dapat menjadi landasan dalam melakukan pengamatan selanjutnya. Komponen sikap menekankan pada kegiatan dan pola pikir yang dilakukan dan diharapkan dapat menjadi sikap yang tetap dilakukan dalam setiap aktivitas kehidupan. Dengan pemahaman atas hakekat Kimia sebagai bagian dari IPA diharapkan menjadi latar belakang dan modal bagi pendidik untuk memahami pembelajaran Kimia yang berkualitas baik. Pada pokoknya, guru atau pendidik melaksanakan tugas pembelajaran Kimia di dalam kelas, namun jika berhasil bukan tidak mungkin hal itu menyebabkan siswa aktif belajar Kimia di dalam kelas maupun di luar kelas.

\section{Metode Pembelajaran PQ4R Pentingnya Metode Belajar}

Pengalaman awal bisa dibangun melalui aktivitas membaca. Dengan kegiatan ini peserta didik akan memiliki stok of knowledge. Salah satu metode yang dapat dikembangkan agar membaca aktif adalah $P Q 4 R$. Salah satu metode yang paling banyak dikenal untuk membantu siswa memahami dan mengingat materi yang mereka baca adalah metode $P Q 4 R$. Metode ini didasarkan pada metode $P Q R S T$ dan metode $S Q 3 R$. langkah-langkah dalam membaca $P Q 4 R$ adalah sebagai berikut:

a. Preview

Peserta didik menemukan ide-ide pokok yang dikembangkan dalam bahan bacaan bagian-bagian yang bisa dibaca misal bab pengantar, daftar isi, topik maupun sub topik, judul, atau ringkasan suatu bab. Penelusuran ide pokok dapat juga dilakukan dengan membaca satu atau dua kalimat setiap halaman dengan cepat.

b. Question

Peserta didik merumuskan pertanyaanpertanyaan untuk dirinya sendiri. Pertanyaan dapat dikembangkan dari yang sederhana menuju pertanyaan yang kompleks. Pertanyaan itu meliputi apa, siapa, di mana, kapan, mengapa, dan bagaimana. Pertanyaan tersebut dikembangkan ke arah pembentukan pengetahuan deklaratif, struktural, dan pengetahuan prosedural.

c. Read

Pada tahap ini peserta didik diarahkan mencari jawaban terhadap semua pertanyaan yang telah dirumuskannya.

d. Reflect

Selama membaca peserta didik tidak hanya cukup mengingat atau menghafal, namun terpenting adalah mereka berdialog dengan apa yang dibacanya. Mereka mencoba memahami apa yang dibacanya. Caranya, (1) menghubungkan apa yang sudah dibacanya dengan hal-hal yang telah diketahui sebelumnya, (2) mengaitkan sub topik di dalam teks dengan konsep-konsep, (3) mengaitkan hal yang dibacanya dengan kenyataan yang dihadapinya.

e. Recite

Pada tahap ini peserta didik diminta merenungkan kembali informasi yang telah dipelajari. Dalam membawakan kembali apa yang telah dibaca dan dipahami oleh peserta didik adalah mereka mampu merumuskan konsep-konsep tersebut, dan mengartikulasikan pokok-pokok penting yang telah mereka bacanya dengan redaksinya sendiri. Akan lebih baik jika peserta didik tidak hanya menyampaikan secara lisan, namun juga dalam bentuk tulisan. 


\section{f. Review}

Langkah terakhir adalah peserta didik diminta membuat rangkuman atau merumuskan inti sari dari bahan yang telah dibacanya. Dalam tahap ini peserta didik mampu merumuskan kesimpulan sebagai jawaban dari pertanyaan-pertanyaan yang telah diajukannya.

Rumusan masalah penelitian adalah Bagaimanakah penerapan Pendekatan Pembelajaran dengan Metode $P Q 4 R$ dapat meningkatkan hasil belajar Ilmu Pengetahuan Alam-Kimia pada siswa kelas XI di SMA Negeri 1 Sibolga tahun 2017/2018?; Bagaimanakah respon siswa terhadap pembelajaran Ilmu Pengetahuan Alam-Kimia pada Pendekatan Pembelajaran dengan Metode $P Q 4 R$ pada siswa kelas XI di SMA Negeri 1 Sibolga tahun 2017/2018?

\section{METODE}

Penelitian ilmiah ini tidak akan dapat dilepaskan dari tahap-tahap yang saling berkaitan. Tahap-tahapan tersebut diantaranya proses penentuan masalah, pencarian data, hingga analisa data secara utuh dan tidak terpisah. Hilang atau tidak dilaksanakannya salah satu tahapan tersebut, maka akan dapat mengurangi atau bahkan menghilangkan bobot kelayakan hasil penelitian. Hal tersebut akan berlaku dalam penelitian yang peneliti laksanakan. Penelitian yang berbasis pada penelitian kelas atau juga dikenal dengan istilah Penelitian Tindakan Kelas (PTK) jaga memerlukan tahapan-tahapan seperti yang disebutkan di atas. Penelitian tindakan kelas merupakan penelitian yang bertujuan sebagai upaya untuk meningkatkan ketrampilan guru atau dosen dan hasil belajar siswa atau mahasiswa. Pengertian tersebut secara tersirat mengandung makna bahwa tujuan utama penelitian tindakan kelas adalah upaya perbaikan dan peningkatan layanan profesionalitas tindakan kelas dalam menangani proses belajar mengajar yang dicapai melalui mendiagnosa keadaan yang direfleksikan.

Sehubungan dengan pelaksanaan penelitian tindakan kelas, maka dalam bab ini peneliti akan jelaskan mengenai hal-hal yang berhubungan dengan penelitian tindakan kelas yang menyangkut tujuan penelitian, waktu dan tempat penelitian, sumber data dan jenis data, variable penelitian, kolaborator, teknik pengumpulan data, desain penelitian, dan teknik analisa data

Penelitian yang dilakukan yaitu Penelitian Tindakan Kelas (Classroom Action Research). Penelitian Tindakan Kelas merupakan jembatan untuk mengatasi berbagai masalah kekurangan penelitian di bidang pendidikan pada umumnya.

Dengan melaksanakan PTK, sebagai peneliti atau guru yang terlibat dalam penelitian ini akan secara langsung mendapatkan metode yang tepat yang dibangun sendiri melalui tindakan yang telah diuji kemanjurannya dalam proses pembelajaran sehingga guru menjadi the theorizing practioner.

Adapun tujuan penelitian ini adalah mengetahui peningkatan hasil belajar mata pelajaran Ilmu Pengetahuan Alam-Kimia pada beberapa materi serta respon peserta didik melalui metode pembelajaran $P Q 4 R$ (Preview, Question, Read, Reflect, Recite and Review) siswa kelas XI SMA Negeri 1 Sibolga.

Penelitian ini dilaksanakan di kelas XI SMA Negeri 1 Sibolga, Kota Sibolga, Provinsi Sumatera Utara.

\section{Teknik Pengumpulan Data}

Dalam hal ini, digunakan beberapa metode untuk menggali informasi yang dibutuhkan. Metode yang dipakai untuk mendapatkan informasi tersebut antara lain sebagai berikut:

a. Metode Tes

Metode tes merupakan serentetan pertanyaan atau latihan serta alat yang lain untuk mengatur keterampilan, pengetahuan, inteligensi, kemampuan atau bakat yang dimiliki oleh individu/ kelompok. Metode ini digunakan untuk mengetahui hasil belajar peserta didik pada mata pelajaran Ilmu Pengetahuan Alam-Kimia pokok bahasan Dinamika Rotasi dan Keseimbangan Benda Tegar kelas XI SMA Negeri 1 Sibolga.

b. Metode Angket

Metode angket merupakan salah satu cara pengumpulan data yang dilakukan dengan cara memberi seperangkat pertanyaanpertanyaan tertulis kepada responden untuk dijawab.4 Metode ini digunakan untuk mengetahui permasalahan yang dihadapi oleh peserta didik dalam pembelajaran Ilmu Pengetahuan Alam-Kimia,

c. Metode Observasi

Yaitu metode pengumpulan data melalui pengamatan dan pencatatan terhadap suatu gejala, proses kerja Dinamika Rotasi dan 
Keseimbangan Benda Tegar. Metode ini digunakan untuk mengetahui pelaksanaan pembelajaran Ilmu Pengetahuan AlamKimia melalui Pendekatan Pembelajaran dengan Metode $P Q 4 R$ pada peserta didik kelas XI.

d. Metode Wawancara

Wawancara dilakukan dengan siswa pada saat observasi awal dan setelah pelaksanaan penelitian. Aspek yang diungkap adalah penggunaan Metode Pembelajaran PQ4R dalam pembelajaran IPA pada siswa kelas IV, solusi yang diambil oleh guru serta kendala yang dihadapi. Hasil wawancara dijadikan sebagai dasar pijakan dalam melakukan proses penelitian. Wawancara selanjutnya dilakukan setelah pelaksanaan penelitian. Hal ini untuk mengungkap keberhasilan penggunaan Metode Pembelajaran PQ4R dalam pembelajaran IPA dapat meningkatkan hasil belajar siswa.

Metode yang digunakan untuk mengumpulkan data dalam penelitian ini adalah dengan:

1) Melihat dokumentasi nilai mata pelajaran Ilmu Pengetahuan Alam-Kimia sebelum penerapan tindakan kelas, sehingga dapat membandingkan prestasi belajar siswa sebelum pelaksanaan tindakan dan setelah diberi tindakan.

2) Melakukan uji tes prestasi dengan menggunakan lembar kerja siswa

3) Observasi data tentang kegiatan pembelajaran melalui lembar observasi

4) Wawancara terhadap siswa tentang Metode Pembelajaran PQ4R yang digunakan.

\section{Desain Penelitian}

Desain penelitian tindakan kelas mengacu pada ketentuan pokok dalam pelaksanaan penelitian tindakan kelas. Ketentuan pokok tersebut tidak lain adalah penerapan empat langkah penting dalam pelaksanaan penelitian tindakan kelas. Keempat langkah tersebut meliputi perencanaan, tindakan, pengamatan dan refleksi yang menjadi satu kesatuan utuh dalam sebuah siklus pembelajaran. Penelitian tindakan kelas ini dirancang dalam empat tahap, yakni tahap pra siklus, siklus pertama, siklus kedua dan siklus ketiga. Adapun langkah-langkah dalam penelitian ini dapat dijelaskan sebagai berikut:

\section{Tahap Pra Siklus}

Tahap pra siklus ini dilaksanakan dalam satu pertemuan. Pada tahap ini, peneliti melakukan hal-hal sebagai berikut:

a. Perkenalan diri

b. Sosialisasi Pendekatan Pembelajaran dengan Metode $P Q 4 R$ yang akan diterapkan dalam pembelajaran Ilmu Pengetahuan Alam-Kimia yang meliputi pengertian, ruang lingkup penerapan, penilaian, aturan main dan penghargaan.

c. Mengumumkan pembagian kelompok

d. Membuat aturan kelas bersama dengan peserta didik untuk dilaksanakan selama proses belajar mengajar

e. Koordinasi dengan ketua kelas dan ketua kelompok, dalam koordinasi ini, peneliti menekankan pentingnya peranan ketua kelompok dalam memberikan dorongan dan motivasi kepada anggota kelompoknya dalam upaya memenangi turnamen. Kemudian masing-masing ketua kelompok tersebut, oleh peneliti diberikan daftar nama anggota kelompok dan ketua kelompok mampu memberikan semangat kepada mereka, maka kelompoknya akan berpetualang mendapatkan poin tambahan. Pada saat koordinasi dengan ketua kelompok, peneliti juga memberikan diktat belajar berupa ringkasan materi ajar Dinamika Rotasi dan Keseimbangan Benda Tegar kepada masing-masing ketua kelompok untuk dibagikan kepada masingmasing anggota kelompoknya sebagai bahan belajar pada pertemuan pertama.

f. Memberikan tugas kelompok untuk belajar di rumah guna mempersiapkan kelompoknya pada pertemuan siklus pertama

\section{Tahap Siklus I}

a. Perencanaan

1) Menyusun rencana pelaksanaan pembelajaran bahan ajar Kimia

2) Pengaturan bangku kelompok

3) Menyusun lembar pengamatan perilaku belajar

4) Penyusun pertanyaan untuk uji pemahaman kompetensi kelompok

5) Merencanakan waktu pelaksanaan penelitian tindakan kelas

b. Pelaksanaan tindakan

Pelaksanaan pada siklus I dilaksanakan dalam satu pertemuan. Pelaksanaan penelitian 
tindakan kelas pada siklus I meliputi:

1) Peneliti menyampaikan semua tujuan pembelajaran yang ingin dicapai

2) Peneliti menyampaikan materi pelajaran Ilmu Pengetahuan Alam-Kimia kelas XI.

3) Peneliti memberikan bahan bacaan kepada siswa untuk dibaca

4) Peneliti menginformasikan kepada siswa bagaimana menemukan ide pokok/tujuan pembelajaran yang hendak dicapai

5) Peneliti menginformasikan kepada siswa untuk membuat pertanyaan makna dari bacaan

6) Peneliti memberikan tugas kepada siswa untuk membuat pertanyaan dari ide pokok yang ditemukan dengan mengumumkan kata-kata apa, mengapa, siapa, dan bagaimana

7) Peneliti memberikan tugas kepada siswa untuk membaca dan menanggapi atau menjawab pertanyaan yang telah disusun sebelumnya

8) Peneliti mensimulasikan atau menginformasikan materi yang ada pada bahan bacaan

9) Peneliti meminta siswa membuat intisari dari seluruh pembahasan pelajaran hari ini

10) Peneliti menugaskan siswa membaca intisari yang dibuatnya dari rincian ide pokok yang ada dalam benaknya

11) Peneliti meminta siswa membaca kembali bahan bacaan, jika masih belum yakin dengan jawabannya

12) Peneliti beserta peserta didik melakukan refleksi terhadap proses belajar mengajar

13) Peneliti memberikan tugas belajar kelompok untuk persiapan pertemuan berikutnya

c. Pengamatan

Pengamatan dalam siklus I meliputi

1) Pengamatan terhadap perilaku belajar yang meliputi kesiapan dalam menerima pelajaran, suasana kelas pada saat akan dimulainya pelajaran, ketaatan terhadap peraturan kelas, keaktifan kelompok

2) Pengamatan terhadap hasil belajar yang didasarkan pencapaian poin oleh masingmasing kelompok. Peserta didik belum bisa beradaptasi dengan proses pembelajaran.

d. Refleksi

1) Melakukan evaluasi terhadap tindakan yang telah dilakukan
2) Secara kolaboratif, antara peneliti dan guru mitra menganalisa dan mendiskusikan hasil pengamatan. Kemudian hasil tersebut menjadi rekomendasi kolaborasi antara peneliti dengan ketua kelompok

3) Mengumumkan tugas kelompok untuk pertemuan siklus kedua

4) Membuat simpulan sementara terhadap pelaksanaan siklus 1I

\section{Tahap Siklus II}

a. Perencanaan

1) Menyusun rencana pelaksanaan pembelajaran Kimia.

2) Pengaturan bangku kelompok.

3) Menyusun lembar pengamatan perilaku belajar.

4) Penyusun pertanyaan untuk uji pemahaman kompetensi kelompok.

5) Merencanakan waktu pelaksanaan penelitian tindakan kelas.

b. Pelaksanaan Tindakan

Pelaksanaan pada siklus II dilaksanakan dalam satu pertemuan. Pelaksanaan penelitian tindakan kelas pada siklus II meliputi:

1) Peneliti menyampaikan semua tujuan pembelajaran yang ingin dicapai

2) Peneliti menyampaikan materi pelajaran Ilmu Pengetahuan Alam-Kimia kelas XI.

3) Peneliti memberikan bahan bacaan kepada siswa untuk dibaca

4) Peneliti menginformasikan kepada siswa bagaimana menemukan ide pokok/tujuan pembelajaran yang hendak dicapai.

5) Peneliti menginformasikan kepada siswa untuk membuat pertanyaan makna dari bacaan.

6) Peneliti memberikan tugas kepada siswa untuk membuat pertanyaan dari ide pokok yang ditemukan dengan mengumumkan kata-kata apa, mengapa, siapa, dan bagaimana.

7) Peneliti memberikan tugas kepada siswa untuk membaca dan menanggapi atau menjawab pertanyaan yang telah disusun sebelumnya

8) Peneliti mensimulasikan atau menginformasikan materi yang ada pada bahan bacaan.

9) Peneliti meminta siswa membuat intisari dari seluruh pembahasan pelajaran hari ini dan pertemuan sebelumnya. 
10) Peneliti menugaskan siswa membaca intisari yang dibuatnya dari rincian ide pokok yang ada dalam benaknya.

11) Peneliti meminta siswa membaca kembali bahan bacaan, jika masih belum yakin dengan jawabannya.

12) Peneliti beserta peserta didik melakukan refleksi terhadap proses belajar mengajar.

c. Pengamatan

Pengamatan dalam siklus II meliputi

1) Pengamatan terhadap perilaku belajar yang meliputi kesiapan dalam menerima pelajaran, suasana kelas pada saat akan dimulainya pelajaran, ketaatan terhadap peraturan kelas, keaktifrja kelompok

2) Pengamatan terhadap hasil belajar yang didasarkan pencapaian poin oleh masingmasing kelompok. Pada tahap ini peserta didik sudah mampu mengkondisikan diri terhadap metode pembelajaran yang telah ditentukan.

d. Refleksi

1) Melakukan evaluasi terhadap tindakan yang telah dilakukan

2) Secara kolaboratif, antara peneliti dan guru mitra menganalisa dan mendiskusikan hasil pengamatan. Kemudian hasil tersebut menjadi rekomendasi kolaborasi antara peneliti dengan ketua kelompok

3) Membuat simpulan sementara terhadap pelaksanaan siklus II.

\section{Teknik Analisis Data \\ Analisis Kualitatif}

Analisis kualitatif digunakan untuk mengetahui perubahan hasil belajar semua siswa pada mata pelajaran. Ilmu Pengetahuan Alam-Kimia, data yang terkumpul dari responden dianalisis secara deskriptif dengan melihat gejala atau tanda-tanda dapat yang dilihat dari kesiapan dalam menerima pelajaran, suasana kelas pada saat akan dimulainya pelajaran, ketaatan terhadap peraturan kelas dan keaktifan dalam kerja kelompok.

Hasil pengamatan dan tes diolah dengan analisis deskriptif untuk menggambarkan keadaan peningkatan pencapaian indikator keberhasilan pembelajaran dengan Kegiatan Belajar menggunakan Metode $P Q 4 R$ dalam pembelajaran yang dapat meningkatkan hasil belajar peserta didik. Pada umumnya, penelitian dengan analisis deskriptif merupakan penelitian non hipotesis. Oleh sebab itu, dalam penelitian ini juga tidak perlu dirumuskan hipotesis.

\section{Analisis Kuantitatif}

Analisis kuantitatif ini digunakan untuk menganalisis hasil belajar siswa pada mata pelajaran Ilmu Pengetahuan Alam-Kimia yang diperoleh dari tindakan I, II, dan tindakan III. Dari data tersebut kemudian diolah dengan mencari prosentase nilai melalui rumus:

a. Rata-rata kelas

Untuk mengetahui nilai rata-rata kelas pada masing-masing siklus digunakan rumus sebagai berikut:

$$
\bar{X}=\frac{\sum X}{N}
$$

Keterangan

$$
\begin{array}{ll}
\bar{X} & \text { : nilai rata-rata kelas } \\
\sum \mathrm{X} & \text { : jumlah nilai siswa } \\
\mathrm{N} & \text { : banyaknya siswa }
\end{array}
$$

b. Ketuntasan belajar secara klasikal

Untuk mengetahui ketuntasan belajar secara klasikal digunakan rumus sebagai berikut:

$$
\mathrm{P}=\frac{\sum n l}{n} \times 100 \%
$$

\section{Keterangan:}

\section{P : Nilai ketuntasan belajar secara klasikal}

$\sum n l$ : jumlah siswa tuntas belajar secara individu n : jumlah total siswa

\section{Indikator Keberhasilan}

Data-data yang diperoleh dari penelitian baik melalui pengamatan, tes atau dengan menggunakan metode yang lain kemudian diolah dengan analisis deskriptif untuk menggambarkan keadaan peningkatan pencapaian indikator keberhasilan tiap siklus dan untuk menggambarkan keberhasilan belajar pelaksanaan Metode Pembelajaran PQ4R pada mata pelajaran Ilmu Pengetahuan Alam-Kimia di kelas XI SMA Negeri 1 Sibolga. Adapun tehnik pengumpulan data yang berbentuk kuantitatif berupa data-data yang disajikan berdasarkan angka-angka maka analisis yang digunakan yaitu presentase dengan rumus 
sebagai berikut:

$$
\text { Nilai }=\frac{\text { Skor yang dicapai }}{\text { Skor maksimal }} \times 100 \%
$$

Keseluruhan data yang dikumpulkan digunakan untuk menilai keberhasilan tindakan dengan indikator keberhasilan. Indikator keberhasilan belajar dari penelitian ini didasarkan pada kriteria ketuntasan minimal (KKM) yang ditetapkan di SMA Negeri 1 Sibolga untuk mata pelajaran Ilmu Pengetahuan Alam-Kimia kelas XI, sebesar 65 dengan ketuntasan belajar sebesar $80 \%$

\section{HASIL PENELITIAN DAN PEMBAHASAN}

Penelitian ini berlangsung 2 (dua) siklus yaitu siklus I dan II, dimana setiap siklus terdiri dari satu pertemuan. Ada 4 tahapan dalam kegiatan penelitian tindakan kelas, antara lain: perencanaan, pelaksanaan tindakan, observasi dan refleksi.

Untuk memperoleh data tentang metode pembelajaran PQ4R (Preview, Question, Read, Reflect, Recite and Review) dalam meningkatkan hasil belajar Ilmu Pengetahuan Alam-Kimia pada peserta didik kelas XI SMA Negeri 1 Sibolga, diperoleh melalui lembar hasil evaluasi peserta didik dan angket tentang respon dan ketertarikan pada metode pembelajaran PQ4R (Preview, Question, Read, Reflect, Recite and Review).

\section{Analisis Pra Siklus}

Kegiatan yang dilaksanakan pada saat pra siklus cenderung merupakan kegiatan pembentukan jaringan kolaborasi antara guru dan peserta didik. Jaringan kolaborasi ini bertujuan untuk meningkatkan motivasi belajar para peserta didik yang masuk dalam kategori kurang dari rata-rata kelas.

Perlu diketahui bawasannya sebelum pelaksanaan pra siklus, peneliti terlebih dahulu berkonsultasi dengan beberapa guru pengampu mata pelajaran Ilmu Pengetahuan Alam-Kimia mengenai kondisi kemampuandalam penguasaan kompetensi dari peserta didik. Secara umum, keduanya menyatakan permasalahan yang menimpa peserta didik adalah masih banyak peseta didik yang memiliki nilai rata-rata kelas dan juga perilaku belajar yang kurang baik yang diindikasikan dengan penerimaan pelajaran dengan seenaknya sendiri. Terkait dengan kemampuan penguasaan kompetensi mata pelajaran, khususnya mata pelajaran Ilmu Pengetahuan Alam-Kimia, peneliti memperoleh data nilai rata-rata peserta didik kelas XI yang masih dibawah rata-rata

\section{Hasil Penelitian Siklus I}

Pelaksanaan pembelajaran siklus I pun dilaksankan. Pada proses pembelajaran siklus I, peneliti melaksanakan pembelajaran dengan menggunakan metode pembelajaran $P Q 4 R$.

Dalam penerapan metode pembelajaran $P Q 4 R$ dengan cara pengajaran biasa yang dilakukan oleh peneliti. Dalam tahap ini peneliti melakukannya dengan cukup baik sehingga peserta didik mengikutinya dengan antusias. Dilanjutkan dengan diskusi kelompok dengan lembar kerja yakni berupa menjawab pertanyaan. Secara rinci hasil dari pembelajaran pada siklus I dapat diuraikan sebagai berikut:

a. Hasil Belajar Siklus I

Tahap berikutnya dalam menerapkan motode pembelajaran $P Q 4 R$ adalah evaluasi pembelajaran berupa tes tertulis, hal ini dilakukan untuk mengetahui evaluasi hasil belajar peserta didik. Pada pembelajaran siklus I hasil belajar peserta didik yang diperoleh mengalami peningkatan bila dibandingkan dengan hasil belajar pada kondisi awal (pra siklus), namun masih belum mencapai indikator keberhasilan yang telah ditentukan yaitu 70. Hasil tes evaluasi yang diperoleh pada siklus I adalah nilai rata-rata tes individu masih dibawah ketuntasan belajar dan ratarata kelas.

b. Hasil refleksi

Berdasarkan hasil observasi siklus I kemudian dilakukan refleksi terhadap langkah-langkah yang telah dilaksanakan. Hasil refleksi tersebut adalah sebagai berikut:

1) Peneliti harus memberi motivasi peserta didik agar lebih semangat dan aktif dalam proses pembelajaran karena pada siklus ini peserta didik kurang aktif dan monoton.

2) Peneliti diharapkan dapat meningkatkan pengelolaan waktu dalam kegiatan pembelajaran sehingga lebih terencana.

3) Peneliti harus lebih maksimal dan merata dalam membimbing peserta didik untuk menyelesaikan tugas kelompokdalam proses pembelajaran. 
4) Adanya penambahan modul sebagai tambahan referensi untuk masing-masing peserta didik, buku paket Ilmu Pengetahuan Alam-Kimia untuk masingmasing kelompok sehingga tiap-tiap kelompok mendapat LKS.Karena untuk mengurangi dominasi kinerja peserta didik yang pandai.

5) Peneliti harus lebih optimal dalam mengevaluasi pembelajaran supaya pemahaman peserta didik lebih mendalam

6) Hasil belajar peserta didik dalam kegiatan pembelajaran belum mencapai indikator keberhasilan yang telah ditentukan sehingga perlu diadakan siklus II.

\section{Hasil Penelitian Siklus II}

Pelaksanaan pembelajaran siklus II dilaksanakan dalam satu kali pertemuan. Untuk tindakan pembelajaran pada siklus II dengan materi Kimia. Tahap awal yang dilakukan dengan guru memberikan motivasi belajar kepada peserta didik supaya peserta didik semangat dalam proses pembelajaran, kemudian peneliiti memberi sedikit penjelasan materi yang akan dipelajari kepada peserta didik. Dilanjutkan dengan diskusi kelompok dengan membuat pertanyaan sesuai dengan langkah-langkah Pendekatan Pembelajaran dengan Metode $P Q 4 R$, dengan bimbingan oleh peneliti. Pada siklus II ini peneliti sudah mampu melakukan pembelajaran dengan baik sehingga peserta didik dapat mengikuti dengan antusias dan senang. Secara rinci siklus II dapat diuraikan sebagai berikut:

a. Hasil Evaluasi siklus II

Pada siklus II ini nilai evaluasi belajar peserta didik meningkat bila dibandingkan dengan nilai evaluasi siklus I yaitu ratarata nilai peserta didik adalah lebih dari 75 dan dengan ketuntasan melibihi $80 \%$ peserta didik.

b. Hasil refleksi

Berdasarkan hasil penelitian siklus II kemudian dilakukan refleksi terhadap langkah-langkah yang telah dilaksanakan. Hasil refleksi tersebut adalah sebagai berikut: Pada pelaksanaan siklus II ini sudah cukup dalam meningkatkan kegiatan aktivitas peserta didik dengan peneliti maupun peserta didik dengan peserta didik dan hasil belajar peserta didik dalam pembelajaran $P Q 4 R$ sudah mencapai indikator yang telah ditentukan.

Tabel 1. Nilai Hasil Belajar dan Ketuntasan Klasikal Peserta Didik

\begin{tabular}{cccc}
\hline \multicolumn{2}{c}{ Siklus I } & \multicolumn{2}{c}{ Siklus II } \\
\hline $\begin{array}{c}\text { Nilai } \\
\text { Rata- } \\
\text { Rata }\end{array}$ & $\begin{array}{c}\text { Ketuntasan } \\
\text { Klasikal }\end{array}$ & $\begin{array}{c}\text { Nilai } \\
\text { Rata- } \\
\text { Rata }\end{array}$ & $\begin{array}{c}\text { Ketuntasan } \\
\text { Klasikal }\end{array}$ \\
\hline $\mathbf{7 0 , 8 6}$ & $73,68 \%$ & 85,46 & $92,11 \%$ \\
& $(28$ Peserta & & $(35$ peserta \\
Didik) & & Didik) \\
\hline
\end{tabular}

\section{Pembahasan Hasil Penelitian}

Pembahasan yang diuraikan di sini didasarkan atas hasil pengamatan yang telah dilakukan dilanjutkan dengan kegiatan refleksi. Dari hasil tersebut dapat diketahui bahwa:

\section{Siklus I}

Selama proses pembelajaran siklus I berlangsung dengan menggunakan metode pembelajaran $P Q 4 R$, peserta didik melakukan kegiatan-kegiatan yang dirancang sesuai dengan silabus dan RPP. Kegiatan-kegiatan yang dilakukan antara lain peneliti memberi penjelasan tentang materi yang akan disampaikan dan tugas-tugas yang harus dilakukan peserta didik dan kelompoknya. Peneliti menjelaskan langkah-langkah pembelajaran. Di akhir pembelajaran peserta didik dibimbing untuk menarik kesimpulan kemudian peneliti memberikan test evaluasi untuk mengetahui penguasaan peserta didik terhadap materi yang telah dipelajari.

Dari pengamatan siklus I diperoleh data hasil pengamatan antara lain peneliti dalam melaksanakan Pendekatan Pembelajaran dengan Metode $P Q 4 R$ kurang optimal. Hal ini disebabkan peneliti kurang memberi motivasi dan bimbingan terhadap peserta didik baik dalam kelompok maupun individu kurang merata sehingga peserta didik menjadi pasif dan kurang memahami materi yang telah disampaikan dan kurang paham tentang jalannya proses Pendekatan Pembelajaran dengan Metode $P Q 4 R$.

Berdasarkan hasil refleksi pada siklus I, dihasilkan antara lain sebagian besar peserta didik dalam melaksanakan Pendekatan Pembelajaran dengan Metode $P Q 4 R$ belum mampu menerapkannya selanjutnya dengan diskusi kelompok masih belum terbiasa. Hal ini 
nampak dari peserta didik yang tidak dapat langsung mengkondisikan diri dalam bentuk kelompok sehingga terjadi keributan. Dalam mengerjakan Lembar Kegiatan Siswa (LKS), interaksi peserta didik dalam kelompoknya seperti saling bertanya, saling menanggapi pendapat, saling menjelaskan, dan saling bekerja sama dalam kelompoknya nampak kurang dan lebih banyak didominasi oleh peserta didik yang pandai, sehingga peserta didik yang lain bersikap pasif, kurang berpartisipasi dan lebih banyak sebagai penonton. Dalam penyajian hasil kerja kelompok ketergantungan pada peserta didik yang pandaipun masih tinggi. Dari hasil evaluasi yang diperoleh ternyata masih belum mencapai indikator keberhasilan yang ditetapkan. Dengan demikian, siklus II perlu dilakukan agar aktivitas dan hasil belajar peserta didik dalam kegiatan pembelajaran dapat meningkat.

\section{Siklus II}

Untuk pelaksanaan pembelajaran siklus II, peneliti mempersiapkan silabus dan RPP secara keseluruhan disusun tidak berbeda dari siklus sebelumnya, tetapi dalam pelaksanaannya lebih diatur dalam setiap kegiatan.

Dari data pengamatan yang diperoleh pada siklus II, pelaksanaantindakan guru sudah baik. Peneliti memberi motivasi belajar dan membimbing peserta didik sudah merata baik secara individu maupun kelompok. Sehingga peserta didik menjadi lebih semangat dan antusias dalam proses pembelajaran. Disamping itu, peserta didik juga menjadi aktif dan mudah memahami materi yang telah disampaikan.

Pada pengamatan siklus II, peserta didik sudah mulai terbiasa dengan adanya diskusi kelompok seperti saling bertanya, saling menanggapi pendapat, saling menjelaskan, dan saling bekerja sama. Serta ketergantungan terhadap peserta didik yang pandai semakin berkurang dan sudah bisa menkondisikan diri dalam kelompok masing-masing.

Dari data pengamatan siklus II hasil belajar yang dicapai dengan nilai rata-rata yang sudah memenuhi nilai minimal kelas dan ketuntasan 90\% dari perserta didik. Dari data tersebut ternyata hasil belajar peserta didik sudah cukup mencapai indikator keberhasilan yang ditentukan. Sehingga siklus II dipandang sudah cukup karena dengan menggunakan metode pembelajaran $P Q 4 R$ dapat meningkatkan hasil belajar peserta didik.

\section{Peningkatan Hasil Belajar Melalui Penerapan Pendekatan Pembelajaran dengan Metode $P Q 4 R$}

Hasil observasi penelitian mengenai peningkatan penguasaan materi belajar pada pembelajaran Ilmu Pengetahuan Alam-Kimia melalui penerapan Pendekatan Pembelajaran dengan Metode $P Q 4 R$ pada siswa kelas XI ini dilakukan dengan menilai hasil tes/evaluasi pada setiap akhir kegiatan pembelajaran. Adapun hasil tes/evaluasi siswa dalam setiap siklus yaitu sebagai berikut:

\section{Analisis Deskriptif Hasil Tes Akhir Pada Siklus I}

Setelah selesai kegiatan dengan beberapa kali pertemuan maka dilaksanakan tes/evaluasi akhir untuk mengetahui hasil belajar siswa setelah dilakukan tindakan pada siklus I. Sebagai hasil analisis deskriptif nilai perolehan hasil belajar pada mata pelajaran Ilmu Pengetahuan Alam-Kimia siswa dapat dilihat pada Tabel 4.2.

Tabel 2. Statistik Nilai Hasil Belajar Pada Siklus I

\begin{tabular}{llc}
\hline No & \multicolumn{1}{c}{ STATISTIK } & $\begin{array}{c}\text { ANGKA } \\
\text { STATISTIK }\end{array}$ \\
\hline $\mathbf{1}$ & Jumlah Siswa & 38 \\
\hline $\mathbf{2}$ & $\begin{array}{l}\text { Kriteria Ketuntasan } \\
\text { Minimal }\end{array}$ & 70 \\
\hline $\mathbf{3}$ & Tuntas & 28 \\
\hline $\mathbf{4}$ & Belum Tuntas & 10 \\
\hline $\mathbf{5}$ & Nilai Tertinggi & 90 \\
\hline $\mathbf{6}$ & Nilai Terendah & 55 \\
\hline $\mathbf{7}$ & Rentang Nilai & 35 \\
\hline $\mathbf{8}$ & (Jangkauan) & Rata-Rata (Mean) \\
\hline $\mathbf{9}$ & Simpangan Baku & 70,86 \\
\hline
\end{tabular}

Bila nilai penguasaan siswa seperti yang ditunjukkan pada Tabel 4.2 kemudian selanjutnya dikelompokkan ke dalam beberapa kategori tingkatan, maka distribusi frekuensi dan presentase nilai penguasaan siswa hasil belajar pada mata pelajaran Ilmu Pengetahuan Alam-Kimia dapat diperlihatkan pada Tabel 4.3 berikut. 
Tabel 3. Distribusi Frekuensi dan Presentase Penguasaan Siklus I

\begin{tabular}{clcc}
\hline $\begin{array}{c}\text { RENTANG } \\
\text { NILAI }\end{array}$ & \multicolumn{1}{c}{ KATEGORI } & $\begin{array}{c}\text { FREKUENSI } \\
\text { (Orang) }\end{array}$ & $\begin{array}{c}\text { PRESENTASE } \\
(\mathbf{\%})\end{array}$ \\
\hline $0-35$ & Sangat Rendah & 0 & 0 \\
$36-69$ & Rendah & 10 & 26,32 \\
\hline & Tidak Tuntas & 10 & 26,32 \\
\hline $70-79$ & Sedang & 14 & 46,84 \\
$80-89$ & Tinggi & 12 & 31,58 \\
$90-100$ & Sangat Tinggi & 2 & 5,26 \\
\hline & Tuntas & $\mathbf{2 8}$ & $\mathbf{7 3 , 6 8}$ \\
\hline & TOTAL & $\mathbf{3 8}$ & $\mathbf{1 0 0}$ \\
\hline
\end{tabular}

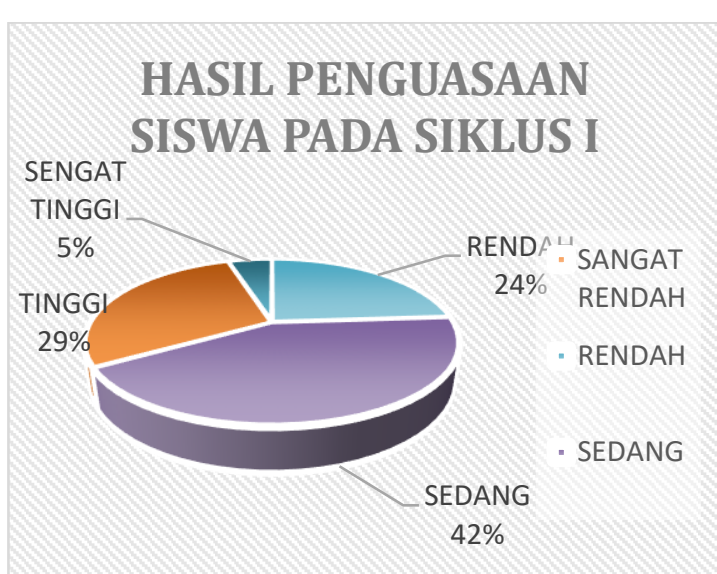

Gambar 1. Diagram Hasil Penguasaan Siswa Pada Siklus I

\section{Analisis Deksriptif Hasil Tes Akhir Pada Siklus II}

Analisis deskriptif dari penguasaan materi dalam bentuk nilai hasil belajar siswa, seperti yang disajikan pada Tabel 4.4.
Tabel 4. Statistik Nilai Hasil Belajar Pada Siklus II

\begin{tabular}{|c|c|c|}
\hline No & STATISTIK & $\begin{array}{c}\text { ANGKA } \\
\text { STATISTIK }\end{array}$ \\
\hline 1 & Jumlah Siswa & 38 \\
\hline 2 & $\begin{array}{l}\text { Kriteria Ketuntasan } \\
\text { Minimal }\end{array}$ & 70 \\
\hline 3 & Tuntas & 35 \\
\hline 4 & Belum Tuntas & 3 \\
\hline 5 & Nilai Tertinggi & 95 \\
\hline 6 & Nilai Terendah & 65 \\
\hline 7 & $\begin{array}{l}\text { Rentang Nilai } \\
\text { (Jangkauan) }\end{array}$ & 30 \\
\hline 8 & Rata-Rata (Mean) & 85,46 \\
\hline 9 & Simpangan Baku & 7,482 \\
\hline $\begin{array}{l}\text { ditu } \\
\text { dike } \\
\text { distı } \\
\text { bela } \\
\text { ditu }\end{array}$ & $\begin{array}{l}\text { Dari hasil belaj } \\
\text { jukkan pada } \\
\text { ompokkan menjadi } \\
\text { ibusi frekuensi dan } \\
\text { ar siswa pada sik } \\
\text { jukkan pada Tabel } 4\end{array}$ & $\begin{array}{l}\text { swa seperti yang } \\
\text { l } 4.4 \text { dapat } \\
\text { egorisasi sebagai } \\
\text { entasi nilai hasil } \\
\text { II, seperti yang } \\
\text { rikut. }\end{array}$ \\
\hline
\end{tabular}

Tabel 5. Distribusi Frekuensi dan Presentase Penguasaan Siklus II

\begin{tabular}{clcc}
\hline $\begin{array}{c}\text { RENTANG } \\
\text { NILAI }\end{array}$ & \multicolumn{1}{c}{ KATEGORI } & $\begin{array}{c}\text { FREKUENSI } \\
\text { (Orang) }\end{array}$ & $\begin{array}{c}\text { PRESENTASE } \\
(\boldsymbol{\%})\end{array}$ \\
$\mathbf{0 - 3 5}$ & Sangat Rendah & 0 & 0 \\
$\mathbf{3 6 - 6 9}$ & Rendah & 3 & 7,89 \\
\hline & Tidak Tuntas & 3 & 7,89 \\
\hline $\mathbf{7 0}-\mathbf{7 9}$ & Sedang & 7 & 18,42 \\
$\mathbf{8 0}-\mathbf{8 9}$ & Tinggi & 20 & 52,63 \\
$\mathbf{9 0 - 1 0 0}$ & Sangat Tinggi & 8 & 21,05 \\
\hline & Tuntas & 35 & 92,11 \\
\hline & TOTAL & 38 & 100 \\
\hline
\end{tabular}




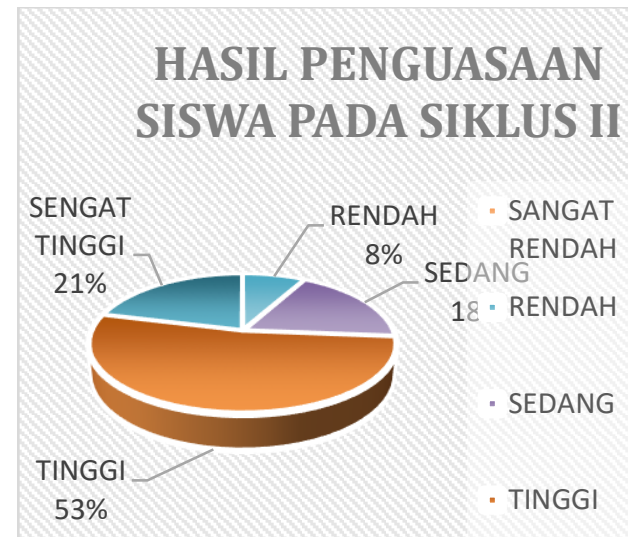

Gambar 2. Diagram Hasil Penguasaan Siswa Pada Siklus II

Kemudian dilakukan pengelompokkan terhadap tingkat ketuntasan belajar siswa dari tes awal, tes akhir siklus I, sampai pada tes akhir siklus II dapat dilihat pada Tabel 4.7.

Tabel 6. Tingkat Ketuntasan Belajar Siswa

\begin{tabular}{cccccc}
\hline NO & KEGIATAN & $\begin{array}{c}\text { JUMLAH } \\
\text { TUNTAS }\end{array}$ & $\begin{array}{c}\text { PRESENTASE } \\
(\boldsymbol{\%})\end{array}$ & $\begin{array}{c}\text { JUMLAH } \\
\text { TIDAK } \\
\text { TUNTAS }\end{array}$ & $\begin{array}{c}\text { PRESENTAS } \\
\mathbf{E} \\
(\boldsymbol{\%})\end{array}$ \\
\hline $\mathbf{1}$ & TES SIKLUS I & 28 & 73,68 & 10 & 26,32 \\
\hline $\mathbf{2}$ & TES SIKLUS II & 35 & 92,11 & 3 & 7,89 \\
\hline
\end{tabular}

Tingkat ketuntasan belajar siswa pada Tabel 4.7 dapat juga dilihat melalui diagram batang seperti pada Gambar 4.4 berikut.

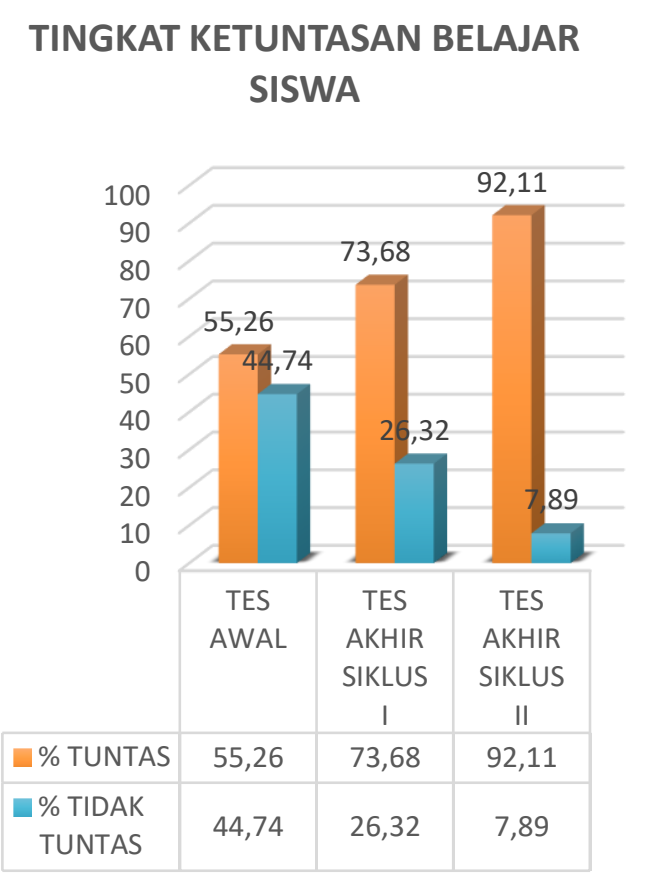

Gambar 3. Diagram Batang Tingkat Ketuntasan Belajar Siswa
Dari Tabel 4.8 dan diagram batang pada Gambar 4.4 menunjukkan tingkat ketuntasan belajar siswa yang terjadi peningkatan. Dimana hal ini menunjukkan prestasi belajar siswa setelah dilakukan tindakan kelas baik pada siklus I maupun siklus II terjadi peningkatan yang sangat signifikan.

Secara umum dapat disimpulkan bahwa hasil belajar siswa setelah dilakukan tindakan kelas khususnya penerapan pembelajaran melalui Pendekatan Pembelajaran dengan Metode $P Q 4 R$ dalam materi pelajaran IPA di kelas XI telah terjadi peningkatan yang sangat signifikan.

Tingkat prestasi belajar siswa setelah melaluai beberapa tahap kegiatan pada tes awal, tes akhir siklus I, dan tes akhir siklus II dapat dilihat pada Tabel 4.9 berikut.

Tabel 7. Tingkat Prestasi Hasil Belajar Siswa

\begin{tabular}{cccc}
\hline NO & STATISTIK & $\begin{array}{c}\text { TES } \\
\text { AKHIR } \\
\text { SIKLUS } \\
\text { I }\end{array}$ & $\begin{array}{c}\text { TES } \\
\text { AKHIR } \\
\text { SIKLUS } \\
\text { II }\end{array}$ \\
\hline $\mathbf{1}$ & Nilai Rata-Rata & 70,86 & 85,46 \\
\hline $\mathbf{2}$ & Nilai Tertinggi & 90 & 95 \\
\hline $\mathbf{3}$ & Nilai Terendah & 55 & 65 \\
\hline
\end{tabular}


Selanjutnya tingkat prestasi belajar siswa pada siklus I dan siklus II sebagaimana yang terdapat pada Tabel 4.9 dapat juga ditunjukkan dengan diagram pada Gambar 4.2 berikut.

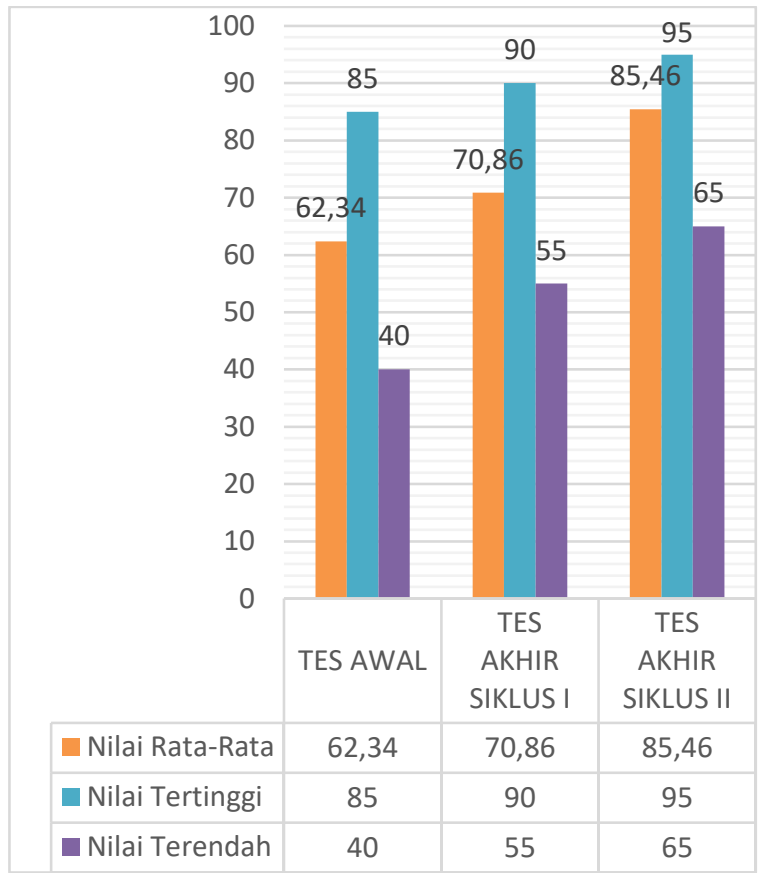

Gambar 4. Tingkat Prestasi Belajar Siswa

Berdasarkan keseluruhan pembahasan di atas maka dapat diambil suatu kesimpulan terhadap hipotesis yang diajukan, yaitu "Adanya kenaikan penguasaan di setiap materi bahan ajar dalam pembelajaran Ilmu Pengetahuan Alam-Kimia setelah diberikan tindakan kelas dengan Metode Pembelajaran $P Q 4 R$ " dapat diterima sebagai suatu kebenaran.

Pada pra siklus atau kegiatan awal sebelum siklus I dilakukan, guru menjelaskan materi pada siswa melalui Pendekatan Pembelajaran dengan Metode PQ4R. Berdasarkan hasil penelitian tindakan pra siklus diketahui hasil belajar siswa belum memuaskan. Ketuntasan belajar klasikal baru mencapai $55,26 \%$ dengan nilai rata-rata 62,34 .

Terdapat peningkatan signifikan pada hasil belajar siklus I menunjukkan adanya kemajuan walaupun belum memuaskan namun terlihat ada peningkatan dari siklus I. Pada siklus I rata-rata nilai belajar sudah tercapai, namun belum melebihi angka 70, karena ketuntasan pada siklus I baru mencapai $73,68 \%$ dengan nilai rata-rata 70,86

Pada siklus II ketuntasan belajar dan rata-rata nilai sudah tercapai, karena pada siklus II ini ketuntasan sudah mencapai 92,11\% dengan nilai rata-rata 85,46. Maka pembelajaran Ilmu Pengetahuan Alam-Kimia melalui Pendekatan Pembelajaran dengan Metode $P Q 4 R$ berpengaruh terhadap penguasaan materi belajar terhadap siswa, hal ini dapat terlihat dengan adanya peningkatan pada ketuntasan belajar perorangan dan ketuntasan belajar.

\section{Peningkatan Keaktifan Siswa Melalui Penerapan Pendekatan Pembelajaran dengan Metode $P Q 4 R$}

Hasil observasi penelitian mengenai peningkatan keaktifan siswa pada materi belajar mata pelajaran Ilmu Pengetahuan Alam-Kimia melalui penerapan Pendekatan Pembelajaran dengan Metode $P Q 4 R$ pada siswa kelas XI SMA Negeri 1 Sibolga ahun pelajaran 2017/2018 ini dilakukan dengan menilai keaktifan siswa dalam kegiatan pembelajaran antara lain lain seperti mengajukan dan menjawab pertanyaan, berpendapat, membuat laporan ataupun kegiatan presentasi siswa.

Hasil penilaian guru terhadap keaktifan siswa pada pembelajaran Ilmu Pengetahuan Alam-Kimia pada siklus I dan siklus II dapat dilihat pada Tabel berikut:

Tabel 8. Nilai Keaktifan Peserta Didik

\begin{tabular}{llcl}
\hline No & $\begin{array}{l}\text { Keaktifan } \\
\text { Peserta Didik }\end{array}$ & Siklus I & $\begin{array}{l}\text { Siklus } \\
\text { II }\end{array}$ \\
\hline $\mathbf{1}$ & $\begin{array}{l}\text { Mengajukan } \\
\text { Pertanyaan }\end{array}$ & $35,00 \%$ & $65,00 \%$ \\
\hline $\mathbf{2}$ & $\begin{array}{l}\text { Menjawab } \\
\text { Pertanyaan }\end{array}$ & $40,00 \%$ & $70,00 \%$ \\
\hline $\mathbf{3}$ & $\begin{array}{l}\text { Mengemukakan } \\
\text { Pendapat }\end{array}$ & $40,00 \%$ & $65,00 \%$ \\
\hline $\mathbf{4}$ & Membuat Laporan & $65,00 \%$ & $85,00 \%$ \\
\hline $\mathbf{5}$ & $\begin{array}{l}\text { Mempresentasikan } \\
\text { Hasil Kegiatan }\end{array}$ & $60,00 \%$ & $95,00 \%$ \\
\hline & Rata-Rata & $48,00 \%$ & $76,00 \%$ \\
\hline
\end{tabular}




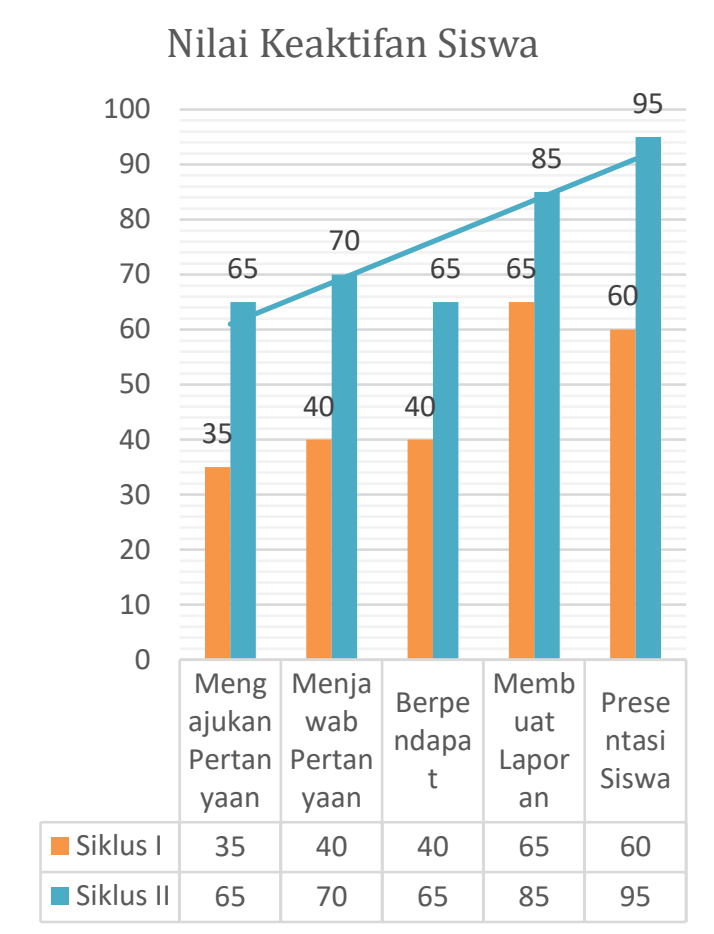

\section{Gambar 4.5. Nilai Keaktifan Peserta Didik}

Jadi dapat dibuat suatu kesimpulan, bahwa dengan penerapan Pendekatan Pembelajaran dengan Metode $P Q 4 R$ telah menghasilkan perubahan pada keaktifan siswa dalam kegiatan belajar mengajar Ilmu Pengetahuan Alam-Kimia. Dimana siswa menjadi lebih aktif dalam bertanya maupun menjawab suatu pertanyaan yang diberikan guru, siswa lebih aktif untuk berpendapat, siswa lebih giat dalam pembuatan laporan atau ringkasan, dan yang paling penting siswa lebih percaya diri dalam kegiatan presentasi dengan teman-teman di kelas.

\section{PENUTUP}

Berdasarkan hasil penelitian yang penulis lakukan tentang penerapan metode pembelajaran PQ4R (preview, Question, Read, Recite, Reflect and Review) sebagai salah satu upaya dalam meningkatkan hasil belajar, dapat diambil suatu kesimpulan bahwa:

a. Hasil belajar peserta didik dengan penerapan metode pembelajaran PQ4R dalam mata pelajaran Ilmu Pengetahuan Alam-Kimia yaitu dari nilai hasil belajar. Terdapat peningkatan signifikan pada hasil belajar siklus I menunjukkan adanya kemajuan walaupun belum memuaskan namun terlihat ada peningkatan dari siklus I. Pada siklus I rata-rata nilai belajar sudah tercapai, namun belum melebihi angka 70, karena ketuntasan pada siklus I baru mencapai 73,68\% dengan nilai rata-rata 70,86. Selanjutnya, pada siklus II ketuntasan belajar dan rata-rata nilai sudah tercapai, karena pada siklus II ini ketuntasan sudah mencapai $92,11 \%$ dengan nilai rata-rata 85,46. Maka pembelajaran Ilmu Pengetahuan Alam-Kimia menggunakan Pendekatan Pembelajaran dengan Metode $P Q 4 R$ berpengaruh terhadap penguasaan materi belajar terhadap siswa, hal ini dapat terlihat dengan adanya peningkatan pada ketuntasan belajar perorangan dan ketuntasan belajar.

b. Respon peserta didik dalam proses pembelajaran menggunakan Pendekatan Pembelajaran dengan Metode $P Q 4 R$ (Preview, Question, Read, Reflect, Recite and Review) dari data angket diperoleh hasil rata-rata $85 \%$. Jadi, penerapan Pendekatan Pembelajaran dengan Metode $P Q 4 R$ telah menghasilkan perubahan pada keaktifan siswa dalam kegiatan belajar mengajar Ilmu Pengetahuan Alam-Kimia. Dimana siswa menjadi lebih aktif dalam bertanya maupun menjawab suatu pertanyaan yang diberikan guru, siswa lebih aktif untuk berpendapat, siswa lebih giat dalam pembuatan laporan atau ringkasan, dan yang paling penting siswa lebih percaya diri dalam kegiatan presentasi dengan teman-teman di kelas.

\section{DAFTAR PUSTAKA}

Almatsier, Sunita, Prinsip Dasar Ilmu Gizi, Jakarta: PT Gramedia Pustaka Utama, 2006.

Arikunto, Suharsimi, Penelitian Tindakan Kelas, Jakarta: Bumi Aksara, 2008

Arikunto, Suharsimi, Prosedur Penelitian Suatu Pendekatan Praktek, Jakata: Rineka Cipta, 2002

Baharudin dan Esa Nur Wahyuni, Teori Belajar Dan Pembelajaran, Yogyakarta: ArRuzz, 2007

Hadi, Amirul dan Haryano, Metodologi Penelitian Pendidikan, Bandung: Pustaka Setia, 1998.

Hadjar, Ibnu, Dasar-dasar Metodologi Kuantitatif dalam Pendidikan, Jakarta: Raja Grafindo Persada,1996

Margono, S., Metodologi penelitian Pendidikan, Jakarta: Rineka Cipta, 2000

Poerdarwinta, Kamus Umum Bahasa Indonesia, Jakarta: Balai Pustaka, 2003. 
Mulyasa, E., Kurikulum Tingkat Satuan Pendidikan, Bandung: Rosdakarya, 2000,

Oemar Hamalik, Psikologi Belajar dan Mengajar, Bandung: Sinar Baru Algensindo, 2004.

Poerwadarwinta, Wjs., Kamus Umum Bahasa Indonesia Edisi 3 Jakarta: Balai Pustaka, 2006.

Purwanto, M. Ngalim, Prinsip-Prinsip Dan Teknik Evaluasi Pengajaran, Bandung: Remaja Rosda Karya, 1998.

Sitorus, MH., Istilah-istilah Biologi, Bandung: Irama Widjaya, 1999.

Slameto, Belajar Dan Fakto-Faktor Yang Mempengarihinya, Jakarta: Rineka Cipta, 1995.
Subagyo, Joko, Metode Penelitian dalam Teori dan Praktek, Jakarta: Rineka Cipta, 1991. Sudjana, Nana, Dasar-Dasar Proses Belajar Mengajar, Bandung: Sinar Baru Algesindo, 2005.

Sugiyono, Metode Penelitian Pendidikan (Pendidikan Kualitatif, Kuantitatif dan $R$ \& D), Bandung: Alfabeta, 2007.

Trianto, Metode-Metode Pembelajaran Inovatif Berorientasi Konstruktifitas, Jakarta: Prestasi Pustaka, 2007.

Wiriatmadja, Rochiati, Metode Penelitian Tindakan Kelas Untuk Meningkatkan Kinerja Guru Dan Dosen, Bandung: Remaja Rosdakarya, 2005. 